\title{
Musikalitet som förmåga till närvaro, struktur och flöde: Ett centralt begrepp i skådespelares lärande
}

Sven Bjerstedt

Teaterhögskolan, Malmö

\begin{abstract}
Denna artikel undersöker vilken betydelse och potential som begreppet musikalitet kan ha för skådespelares lärprocesser. Studien riktar sig främst till lärare och forskare vid landets högre konstnärliga utbildningar. Betraktad som professionsforskning och som exempel på språkliga metaforers potential i konceptualiserings- och lärandeprocesser bör den emellertid kunna vara av intresse även för andra läsare. Det nämnda intermediala begreppslånet kan uppfattas som en metafor som är av central betydelse när konstnärer, pedagoger och andra talar om teater. En teaterhistorisk översikt pekar på rytm som en central aspekt av den innebörd som har tillskrivits begreppet musikalitet inom teatern. Analyser av två omfattande intervjustudier med konstnärer och pedagoger på teaterområdet pekar på att begreppet musikalitet framstår som central i intervjuernas perspektiv på kvalitet i skådespelarens arbete. Den bild som framtonar av musikalitetens innebörd på teaterns område är komplex. Förmågan att agera musikaliskt kan uppfattas som sammansatt av en rad förmågor som kompletterar varandra, här betecknade med nyckelorden närvaro, struktur och flöde. En lockande uppgift för framtida forskning är att undersöka vilken potential detta sätt att uppfatta innebörden av begreppet musikalitet kan ha på begreppets ursprungsområde, musiken.
\end{abstract}

\section{INLEDNING}

Begreppet musikalitet har stor betydelse i teaterns språkbruk, både rörande hur teatern historiskt har utvecklats genom att på olika sätt närma sig musiken (Roesner, 2014) och med syftning på en kvalitet i skådespeleri, som i 
allmänhet framställs som eftersträvansvärd (Bjerstedt, 2017). Den här artikeln tar fasta på den senare begreppsanvändningen och studerar musikalitetsbegreppets innebörder och potential för skådespelares lärande. Detta intermediala begreppslån kan uppfattas som en metafor av central betydelse när konstnärer och pedagoger på teaterområdet formulerar sig om sin verksamhet - men dess innebörd är otillräckligt undersökt (Bjerstedt, 2017). I artikeln refereras och analyseras två studier (Bjerstedt, 2010; 2017) av hur svenska professionella teaterutövare och teaterpedagoger uppfattar innebörden av att agera musikaliskt. De empiriska undersökningar som här presenteras utgör försök att besvara två frågeställningar: Hur använder utövare och pedagoger det lånade begreppet 'musikalitet' som beskrivning av kvaliteter och förmågor på talteaterns område? Vilken potential kan detta begrepp ha för skådespelares lärandeprocesser? Artikeln riktar sig primärt till lärare och forskare på landets högre konstnärliga utbildningar; betraktad som professionsforskning bör studien emellertid kunna vara av intresse även för andra yrkesgrupper.

\section{LÄRANDE GENOM METAFORISKA BEGREPPSLÅN}

I Platons dialog Menon formuleras en grundläggande pedagogisk paradox: hur kan något nytt läras? När man redan har kunskap beböver man inte söka efter den, och när man inte har kunskap kan man inte söka efter den, eftersom man inte vet vad man skall söka efter (och om man råkar finna den, har man ändå inget säkert sätt att identifiera den som den sökta kunskapen).

Språkliga metaforers potential i konceptualiserings- och lärandeprocesser har studerats av både metaforteoretiker och utvecklingspsykologer (se exempelvis Lakoff \& Johnson, 1980; Johnson, 1987; Swanwick, 1988). Petrie och Oshlag (1993) har pekat på den interaktiva metaforen (Black, 1962) som ett sätt att upplösa Menon-paradoxen: "metaphor is one of the central ways of leaping the epistemological chasm between old knowledge and radically new knowledge" (Petrie \& Oshlag, 1993, s. 585). I kraft av både sin förmåga att skapa likheter och sin motsägelsefulla karaktär, hävdar författarna, har den interaktiva metaforen potential att överföra "chunks of knowledge" och att "allow truly new forms of knowledge and understanding" (s. 583, 587).

I musikpedagogiska sammanhang har metaforiskt språkbruk visats vara vanligt, särskilt beträffande undflyende ("intangible", "elusive") uttryckskvaliteter (Schippers 2006, s. 210). Iakttagelsen kan generaliseras till hela det konstnärliga fältet. Ett egendomligt fenomen inom konstnärlig kunskapsbildning och konstnärligt lärande är hur metaforiska lån av begrepp från en annan konstart kan användas för att uttrycka något centralt om den egna konstarten (Bjerstedt, 2010; 2014; 2017). När instrumentalmusikern spelar används exempelvis inga ord, men motsägelsefullt nog har ändå begrepp som 'berättande' eller 'storytelling' fått en framskjuten plats som beskrivning och 
rekommendation beträffande en central aspekt av musicerande, exempelvis inom jazzmusiken (Bjerstedt, 2014). Somlig nutida talteater musikläggs förvisso, men när en talskådespelare agerar (och utbildas att agera) förekommer i normalfallet ingen musik; ändå använder teaterns utövande konstnärer, kritiker och pedagoger med förkärlek termen 'musikalitet' för att förklara och värdera skådespelarinsatserna (Bjerstedt, 2010; 2017).

Det har visat sig att det bland konstnärer och konstnärliga forskare förekommer vitt skilda uppfattningar om och förhållningssätt till en rad nyckelbegrepps innebörder på det konstnärliga området (Lind \& Bornholm, 2013, s. 196). I kontrast till denna iakttagelse kan man konstatera en påfallande konsensus beträffande de ovannämnda metaforiska, intermediala begreppslånen (Bjerstedt, 2010; 2014; 2017). Den här artikelns syfte är att utforska konstnärlig kunskapsbildning och konstnärligt lärande på teaterområdet genom att studera musikalitetsbegreppets innebörder och pedagogiska potential.

\section{MUSIKALITET SOM NYCKELORD I TEATER OCH TEATERPEDAGOGIK}

Ursprungligen var konstarterna mer integrerade, och musik har utgjort en väsentlig beståndsdel i den västerländska teatern under dess långa historia. I andra kulturer finns på flera håll ännu en tät, rentav oupplöslig koppling mellan teater och musik. Men i den västerländska talteatern är nu åtskillnaden mellan konstarterna relativt distinkt. Den nutida renodlade talteatern förses visserligen emellanåt med musikinslag, men talteatern skulle trots detta kunna betraktas som en drygt sekellång "parentes" av musiklös teater (Johansson, 2006, s. 26).

Bland dagens talskådespelare tycks ändå finnas en massiv konsensus kring musikalitetens betydelse för teatern. Att begreppet spelar en betydelsefull roll i teaterns språkbruk är ovedersägligt (Bjerstedt, 2017, s. 11-20). En studie hävdar rentav att "det är nödvändigt för en skådespelare att vara musikalisk. Musikaliteten yttrar sig $i$ allt från texthanteringen till det sätt man rör på sin kropp" (Helander, 2007, s. 35). Men övergripande, analytiska undersökningar på området är överraskande sällsynta.

Begreppet musikalitet förekommer i teatersammanhang ofta i metaforisk eller metafysisk användning (Staniewski \& Hodge, 2003, s. 63; Boleslavsky, 1933/2003, s. 132). Överlag presenteras begreppet musikalitet på teaterområdet ofta $\mathrm{i}$ ganska allmänna ordalag: man nämner exempelvis röstens, kroppens eller textens musikalitet utan att begreppsinnebörden klargörs närmare (Bjerstedt, 2017, s. 11-20).

Man har kunnat uppfatta förhållandet mellan musik och teater som en fråga om översättning. Den rysk-amerikanske teatermannen Michael Chekhov [1891-1955] formulerade exempelvis en rad begrepp och tekniker för skådespelarträning (Ashperger, 2008). En rad av dessa ansluter till begrepp 
som paus, crescendo, diminuendo, melodi, tonart, rytm samt (inre och yttre) tempo (Chekhov, 1992).

En av de mycket få forskare som har skrivit utförligt om musikalitet på teaterområdet är David Roesner (2014). Han använder Michel Foucaults term dispositif för att ringa in hur musikalitetsbegreppet enligt hans mening har kommit att användas i teatern. Ordet är inte alldeles enkelt att översätta; kanske kan man sammanfattningsvis uppfatta det som en samlingsterm för mekanismer och strukturer som möjliggör maktutövande. Roesner (2014) betraktar musikalitet som "a central, influential, transformative and multifaceted dispositif with significant impact on the theatrical landscape of the last 150 years and more" (s. 257). Begreppet kan alltså uppfattas som inte endast deskriptivt; på många sätt fungerar det som ett (så gott som alltid) positivt laddat värdeord.

I denna artikel presenteras emellertid inte någon historisk studie av hur teatern utvecklats genom att på olika sätt närma sig musiken. Här fokuseras i stället utövares och pedagogers synsätt på skådespelarens musikalitet: förkroppsligad, utövad. Artikeln är strukturerad på följande sätt. Efter en kort inventering av hur tidigare musikalitetsforskning närmat sig frågan om musikalitet på andra fält än musiken följer en översiktlig studie av hur musikalitetsbegreppet i förhållande till en teaterhistorisk utveckling (sammanfattad under rubrikerna retorik, realism och modernism) huvudsakligen tycks inriktat på rytm. Därefter refereras två intervju-undersökningar av hur musikalitetsbegreppet används inom nutida svensk teater och teaterpedagogik (Bjerstedt, 2010; 2017). Avslutningsvis formuleras en analys av hur skådespelarens musikalitet enligt dessa synsätt tycks kunna uppfattas som en kombination av förmågor, här sammanfattade under rubrikerna närvaro, struktur och flöde.

\section{MUSIKALITET UTAN MUSIK?}

Musikalitetsforskningens definitionsförsök beträffande musikalitetsbegreppet har av naturliga skäl som regel brukat innehålla hänvisningar till musik. Jørgen Pauli Jensen (1970) föreslår emellertid att också "estetiska kategorier" i vid mening (exempelvis komisk, tragisk, grotesk, absurd) kan utgöra ett fält av intresse för musikalitetsforskningen (s. 99 f). Här finns en antydan om att musikalitet kan vara ett relevant begrepp även bortom musikens gränser. Liknande yttranden förefaller sällsynta i musikalitetslitteraturen. Ett av de få jag hittat är Sture Brändströms (2006) påpekande om den relationella eller kommunikativa aspekten av musikalitetsbegreppet som ett komplement till huvudperspektiven absolut och relativistisk musikalitet.

Med absolut musikealitet förstår Brändström (1997, 2006) synsättet att vissa människor så att säga har musikalitet inom sig, med relativistisk musikalitet att 
alla människor anses vara musikaliska i den meningen att de har både förmåga att uppleva musik och att uttrycka sig musikaliskt, under förutsättning att miljöbetingelserna är gynnsamma. En av Brändströms intervjupersoner anför följande kriterium på musikalitet, som jag uppfattar som särskilt tänkvärt och utvecklingsbart i relation till en studie av musikalitet på teaterområdet: "det låter som ett tal, det andas och det finns ett naturligt flöde" (Brändström, 2006, s. 149).

Brändström (2006) har kompletterat de två nämnda perspektiven med ett tredje, relationell musikalitet, vars tyngdpunkt ligger på musikens kommunikativa aspekter; man kan jämföra med Malloch och Trevarthens (2008) begrepp communicative musicality. Brändström (2006) framhåller en aspekt av ett hermeneutiskt synsätt som särskilt viktig, nämligen den att konstens bärande element är kommunikation, viljan att meddela sig med andra. Sammanfattningsvis konstaterar han att

utifrån de hermeneutiska grundantaganden som denna text vilar på, talar det mesta för ett relationellt perspektiv. Även om texten primärt behandlar musikområdet, så är det inte ett alltför vågat påstående att resonemangen om kommunikation i stora stycken är överförbara till andra delar av det estetiska fältet. (s. 154)

Brändströms uttalande är av särskilt intresse för en undersökning av musikalitetsbegreppet på teaterområdet. Den kommunikativa aspekten av musikalitetsbegreppet erbjuder en länk till andra delar av det estetiska fältet, inte minst teatern. Sådana sammankopplingar mellan konstarterna är ytterst sällsynta i den musikalitetslitteratur som jag har inventerat.

\section{NÅGRA HISTORISKA PERSPEKTIV PÅ TEATERMUSIKALITET}

Framställningen i detta avsnitt syftar inte till någon heltäckande historisk framställning utan inskränker sig till några nedslag och glimtar av relevans för den föreliggande undersökningen. Tre skilda ideal får här fungera som beteckningar för ett slags teaterhistoriska paradigm: retorik, realism och modernism.

\section{Det retoriska teateridealet}

Som konstform har teatern genom hela sin historia varit en hybrid: från sitt antika ursprung fram till vår tids multimediala och multimodala sceniska praktik. I det antika grekiska dramat var teater och musik i högsta grad integrerade och avhängiga av varandra. Tragedin använde musikaliska inslag som en integrerad del, och de tragiska aktörernas textbehandling hade tydlig sånglig karaktär (Tjäder, 2008). Det grekiska ordet för sång spelade en central roll vid den västerländska dramatikens uppkomst: ordet tragedi härleds ur 
grekiskans trag'os, 'bock', och öidè, ,'sång'. Dramatikern var i den antika teatern inte endast författare utan också ofta spelets ledare, körkoreograf, kompositör och inte sällan den ledande skådespelaren. En dramatiker måste därför även kunna dansa och sjunga; exempelvis ska Sofokles ha varit en skicklig dansare (Tjäder, 2008).

En vanlig företeelse i musik är rörelse mot ökad intensitet. På senare tiders musikspråk har aspekter av en sådan stegring bland annat kommit att betecknas med crescendo och accelerando. Kanske kan man se ett slags scenisk motsvarighet till sådana musikaliska förlopp redan i det antika dramats begrepp stichomyti. Det är beteckningen för ett stegrande, känslomässigt laddat meningsutbyte format i enradiga repliker som "stegras till den punkt där ingenting mer kan sägas" (Tjäder, 2008, s. 39).

Den nära kopplingen mellan konstarterna bestod genom århundradena. Under medeltiden och renässansen framfördes musik inte bara i samband med teaterföreställningar, utan den var också en mycket stor del av dem (Brockett, 1995).

Genom historien kännetecknas teatern, liksom andra konstarter, av dynamiken mellan större eller mindre frihet inom den givna formen. En sådan spänning kan ha betydelse för teaterns samband med musik och musikalitet, till exempel beträffande teater i bunden form och teater byggd på improvisation.

Jean Racines höglitterära dramatik har kallats "ordmusik" (Tjäder, 2008, s. 185). En musikalitet med delvis andra förtecken kännetecknar improvisatoriska teaterformer. Skådespelarna i commedia dell'arte kan sägas använda sig av improvisation inom pjäsens ramhandling "ungefär som 1900talets jazzmusiker" improviserar över ett givet tema (Tjäder, 2008, s. 105). När teater ibland betraktas som eller liknas vid musik kan det alltså innebära ganska olika saker, bland annat beroende på om man främst menar improviserad musik eller interpretation av skriven musik.

Genom årtusendena utgör retoriken en viktig länk mellan musiken och teatern. Kanske kan talekonstens historia sägas vara bland annat en historia om musiken i det talade språket. 'Kadens' (harmonisk avslutning) och en rad andra begrepp är också gemensamma för musik och retorik. I äldre tiders konstformer kan teater och musik rentav ses som två uttrycksformer förenade av retoriken, strävan att väcka känslor.

Blankversen användes allmänt bland renässansens engelska dramatiker från 1560-talet (Tjäder, 2008). Den elisabetanska publikens känslighet för textrytm bör ha varit högt uppdriven, menar Berry (1987): ett lyssnande med fokus på ordet. Textrytmen fungerar som bärare av struktur men också av energi (Rodenburg, 2002, s. 92 ff). Jambrytmens flöde och oregelbundheter fungerar för skådespelaren som ersättning för scenanvisningar: rytmens ojämnheter kan understryka sinnesrörelse, och det hackande talet kan signalera hög angelägenhetsgrad (Rodenburg, 2002, s. 97). 


\section{Det realistiska paradigmskiftet}

Ofta förs scenisk musikalitet på tal i samband med komedispel, inte minst den komiska skådespelarens suveräna tajming. Ett accelererande dramatiskt tempo är i hög grad betecknande för den utvecklingslinje som företräds av franska 1800-talsdramatiker som Scribe, Labiche och Feydeau (Tjäder, 2008, s. $207 \mathrm{f}$ ).

Ett exempel på det realistiska teateridealets inriktning på scenisk musikalitet kan hämtas från August Strindberg. Hans ställning som den svenska dramatikens förnyare har oftast studerats och värderats från litteratur- och teaterhistorisk synpunkt, men Strindbergs intressefokus på texten kommer till uttryck i en stor mängd musikaliska föredragsbeteckningar. I ett Memorandum till Intima Teaterns skådespelare (Strindberg, 1908/1999) klär han många av sina instruktioner i musikterminologisk skrud. Strindberg förespråkar exempelvis bundet framförande, legato-tal - dels av estetiska skäl, dels av omsorg om textens innebörd. Vidare påpekar han att texten måste ges rätt tempo och intensitet. Strindberg insisterar också på att skådespelaren måste hitta och odla sitt eget naturliga röstläge: "Att vackla i lägena är att sjunga orent, och 'harmonifrämmande toner' uppträda störande, emedan de införa stämningar som icke höra dit” (Strindberg, 1908/1999, s. 19). För Strindberg tycks rollens ton i denna bemärkelse vara nära kopplad till rollfigurens hållning. Han fäster stor vikt vid att den enskilda rollfiguren bevarar sin inneboende harmoni i förhållande till de övriga rollerna. Strindbergs förtjusning i musiken som metafor för skådespelarkonsten går inte att ta fel på. Hans skådespelarinstruktioner har sin botten i både realism och sagospel. De kan ses som en länk mellan tidigare epokers retoriska ideal och de framväxande modernistiska strömningarna, där ju Strindberg också spelade en betydelsefull roll.

\section{Modernismen}

Så länge dramaturgin har verkligheten som sin utgångspunkt, blir händelseföljdernas kausalitet ett dominerande mönster. När musikaliska element som rytm och klang träder in som dramaturgiska drivkrafter blir förhållandena annorlunda. Ett brett spektrum av konstnärliga uttrycksmedel får genom denna utveckling framträdande plats i teatern: rytmiska element, ordens klang, musikalisering av dramaturgin (Rynell, 2008).

Den moderna teatern bygger $i$ väsentlig grad på influenser från Richard Wagner [1813-1883], inte minst hans idé om musiken som den väsentligaste konstformen och hans vision av musikdramat som en helhet som innefattar både teaterns dialog och sångens uttryck (Tjäder, 2008, s. 305; en monografi om Wagners inflytande på teatern är Carnegy, 2006).

Adolphe Appia [1862-1928] strävar liksom Wagner mot ett musikdrama som ska förverkligas på scenen. Iscensättningen ska byggas efter nya 
principer, i en musikalisk rymd, rytmiserad av tonsättaren (Bergman, 1966, s. 137). Aktörens uppgift blir att förkroppsliga innebörden av det musikaliska förloppet, och för att göra det måste hon ge upp sin individualitet (Tjäder, 2008, s. 364). Under intryck av Dalcrozes rumsligt-rytmiska tänkande applicerar Appia sina principer om kroppens rörelse i musikaliskt genomkomponerade rum, 'éspaces rythmiques', som rytmiseras genom trappor $i$ olika riktningar (Tjäder, 2008, s. 365). Musikaliteten blir för Appia vägen till dramats "inner essence" (Roesner, 2014, s. 257).

I den inflytelserike Konstantin Stanislavskijs [1863-1938] system för skådespelarträning ingår som väsentlig beståndsdel hans övertygelse att människors känslor och handlingar är intimt förknippade med rytm. Stanislavskij fäste mycket stor vikt vid sambandet mellan en pjästexts komplexa stämningar och dess komplexa rytmer. För honom framstod det följaktligen som en central uppgift för den enskilda skådespelaren att upptäcka, urskilja och forma sina egna perspektiv beträffande rytm. Stanislavskij (2008) presenterar begreppet inre och yttre 'tempo-rytm' och exemplifierar hur skådespelaren kan träna detta $\mathrm{i}$ en rad övningar med metronomer och handklapp, kombinerade med inre bilder och sceniska uppgifter. Tempo-rytm står enligt Stanislavskij i nära samband med känslorna, det inre livet. Tempo-rytm blir därför av stor vikt för en pjäs eller en roll genom sin förmåga att utöva omedelbar stimulans på våra känslominnen och vårt inre upplevande.

Vsevolod Meyerhold [1874-1940] kan ses som företrädare för en återteatralisering av teatern (Roesner, 2014, s. 58). I hans övningar beträffande scenisk rörelse är både spatial och temporal rytm av central betydelse. Genom dem utvecklar hans skådespelarstudenter musikalitet, fysisk rörlighet och lyhördhet på scenen (Leach, 2000, s. 41). I en ofta återgiven formulering gör Meyerhold en uttalad parallell mellan konstformerna teater och musik: "if acting is the melody, then the mises en scène are the harmony" (Gladkov, 1996, s. 124).

Stanislavskijs fokus på skådespelaren och Meyerholds fokus på rörelserytmen kan ses som motsatser. Alexander Tairov [1885-1950] eftersträvade en syntes, en teater där både rörelsens och talets rytm "glödde" (Bergman, 1966, s. 369 ff). Jevgenij Vakthangov [1883-1922] utvecklade enligt egen uppgift sin uppfattning om rytmens betydelse oberoende av Stanislavskij (Whyman, 2008, s. 168). Vakthangovs uppsättning av Dibbuk i en judisk studio 1917 innehöll både rytmiskt komponerade rörelsescheman och ordsekvenser som ibland stegrades till sång (Bergman, 1966, s. 375).

Musik och rytm är också centrala element i den expressionistiska teatern. Målaren Oskar Kokoschka [1886-1980] framträder som rytmiskt medveten regissör. En syntes av visionerna om teatern som en rytmisk förening av musik, ord, rörelse, färg och form i ett allkonstverk à la Wagners musikdrama formuleras i den abstrakta teatern hos Wassily Kandinsky [1866-1944]. I hans 
sceniska syntes är musiken central i alla avseenden, genom visuell rörelserytm och körstämmor men också genom ljusväxlingar efter ett rytmiskt schema. Ett besläktat teaterideal, dominerat av elementen form, färg, rörelse och ljud, formuleras också av poeten och dramaturgen Lothar Schreyer [1886-1966]. Han jämför ofta sin abstrakta teater med musik: den grafiska formen är av central betydelse, framförandet av underordnad vikt (Rynell, 2008). För Antonin Artaud [1896-1948] är musikalitet en fråga om något mycket mera primitivt: med Roesners (2014) ord, "the raw energy of sound, the cacophony, the deconstructing and destabilizing effects of sound as friction and interference" (s. 100).

För Louis Jouvet [1887-1951] visar sig livets rytm i talets musikalitet. Textens och andningens rytm är centrala bärare av betydelse och påverkanskraft. Förnuftets roll är underordnad. Det är textrytmen som är nyckeln till åhörarens mottaglighet (Jouvet, 1954, s. 235). Sjögren (2002) anför ett uttalande av Ingmar Bergman [1918-2007] där andhämtning och puls framställs som centrala begrepp för teatern: "all konst har med andhämtning att göra, med pulsens slag, dag och natt" (s. 441).

Sammanfattningsvis framstår rytm som en central aspekt av scenisk musikalitet. Tidiga exempel på hur pjästexters rytmiska utformning kan bära på en intensitetsstegring har vi i det antika dramats användning av stichomyti. Även i renässansens blankvers fungerar pjästextens rytmer som betydelsebärare. Betydelser finns lagrade i textrytmen, och de förverkligas genom textens utförande och mottagande. I den lättare repertoaren längs linjen ScribeFeydeau och in i samtidens farsgenre ser vi hur ett accelererande, intensifierat tempo rentav upphöjs till bärande dramatisk princip. Vidare är den rytmiska rörelsen $i$ rummet en av teaterns allra viktigaste komponenter för många av dess moderna förgrundsgestalter.

\section{SKÅDESPELARENS MUSIKALITET: INTERVJUER MED TEATERKONSTNÄRER OCH TEATERPEDAGOGER}

Intervjuerna genomfördes under åren 2010-11 (Bjerstedt, 2010; 2017). Flera slags överväganden styrde urvalet: jag önskade intervjua erfarna pedagoger och konstnärer med lust och intresse för att samtala om teatermusikalitet, och där konstnärerna helst också hade erfarenheter av att arbeta med teaterpedagogik. Samtliga intervjupersoner har lämnat sitt medgivande till att presenteras utan att intervjumaterialet anonymiseras (Bjerstedt, 2010, 2017). De fem pedagogerna (Bjerstedt, 2010), samtliga verksamma vid Teaterhögskolan i Malmö, är Birgitta Vallgårda (f 1953, professor i scenisk framställning), Marek Kostrzewski (f 1946, universitetslektor i scenisk framställning), Margareta Unné Göransson och Harald Emgård (födda 1949 respektive 1960, båda universitetslektorer i röst, tal och text) samt Barbara 
Wilczek Ekholm (f 1954, universitetslektor i rörelse). De professionella konstnärerna (Bjerstedt, 2017) är Stina Ekblad (f 1954), Gösta Ekman (1939_ 2017), Lena Endre (f 1955), Staffan Göthe (f 1944), Henric Holmberg (f 1946), Mia Höglund Melin (f 1973), Sissela Kyle (f 1957), Rolf Lassgård (f 1955), Ann Petrén (f 1954), Marie Richardson (f 1959), Göran Stangertz (1944-2012), Tobias Theorell (f 1969) och Iwar Wiklander (f 1939).

Mitt sätt att uppfatta och tillämpa forskningsintervjun ansluter till det synsätt som uttrycks av Steinar Kvale (1997). Genom intervjun vill jag nå fram till beskrivningar formulerade av den intervjuade personen i avsikt att tolka och beskriva fenomenens mening. Den explorativa intervjun, som det här är fråga om, syftar inte till att pröva hypoteser. Den är öppen och inte speciellt strukturerad. Den explorativa intervjun syftar till att förstå ämnen ur den intervjuades eget perspektiv. Intervjun bygger upp kunskap - som samtal, som berättelse, som relation.

Kvale (1997) framhåller att sådana explorativa intervjuer kan vidga och förändra forskarens uppfattning. De intervjuade drar fram nya och oväntade aspekter av de studerade fenomenen, och under analysen av de utskrivna intervjuerna kan nya distinktioner upptäckas. Ett av huvudsyftena med en explorativ studie är att upptäcka nya dimensioner hos det ämne som är föremål för undersökningen.

Men undersökningen stannar inte vid att återge samtalen okommenterade. Att välja, ordna och sammanfoga intervjuuttalanden har varit ett omfattande arbete. Om resultaten endast skulle redovisas utifrån informanternas självförståelse, utan att materialet tolkas djupare, mister man en forskningsmässig dimension. I analysen rearrangeras och bryts de olika rösterna mot varandra och, inte minst viktigt, mot mitt sätt att uppfatta och tolka sammanhangen.

En utgångspunkt för excerperingen och analysen har varit ett hermeneutiskt förhållningssätt. Alvesson och Sköldberg (2008) urskiljer fyra aspekter mellan vilka en hermeneutisk tolkning oscillerar: tolkande mönstertext-dialog-partiella tolkningar. Frågor ställs med utgångspunkt i den tolkandes förutfattade meningar. Det aktivt frågande förhållningssättet kompletteras med ett ödmjukt, distanserat förhållningssätt som är grundat i respekt för självständigheten hos det som tolkas. De partiella tolkningarna utarbetas följaktligen $\mathrm{i}$ dialog med texten, vilket medför att forskarens föreställningar undergår förändring under hela tolkningsprocessen. Alvesson och Sköldberg (2008) urskiljer ett ganska stort antal hermeneutiska "teman" som i kombination med den hermeneutiska cirkelns och tolkningsprocessens många aspekter utgör en mångfald perspektiv som kan konfronteras med varandra $\mathrm{i}$ ett hermeneutiskt sökande efter sanningen: att ställa frågor till texten och lyssna på texten; att tränga in i implicita dimensioner av texten; att söka efter att förena olika tolkningshorisonter. För att optimalt konfrontera intervjupersonernas skilda perspektiv i enlighet med de nämnda metodolog- 
iska utgångspunkterna samlades och identifierades under den inledande analysprocessen en mängd potentiellt betydande intervjuuttalanden om musikalitet på teaterområdet. Därigenom fastställdes ett antal kategorier eller tematiska fält. När ytterligare excerpter analyserades, bekräftades och utökades dessa kategorier. Processen kan beskrivas som en kontinuerlig strävan att integrera reflektion och uppmärksamhet, för att därigenom kunna lägga ytterligare insikter till ett framväxande tolkningsmönster på flera nivåer. Härvidlag har en ledstjärna varit varsamhet, $i$ linje med en under tolkningsprocessen framväxande övertygelse om att materialets mångfasetterade rikedom skulle riskera att ogynnsamt reduceras genom alltför hårdhänt tillämpad analytisk systematik. Man bör hålla i minnet det abduktiva - på sätt och vis nästan intuitiva - inslaget i denna reflekterande, tolkande process, liksom dess kontinuerliga samspel mellan intervjudata, hypotetiska slutsatser och teoretiska perspektiv.

Som svar på en inledande fråga om vad som kännetecknar en bra skådespelarinsats tar de intervjuade professionella teaterarbetarna en rad termer från vardagsspråket till hjälp för att beskriva viktiga kvaliteter i skådespeleri: exempelvis liv, trygghet, närvaro, fokus, mod och kommunikation (Bjerstedt, 2017, s 69-80). Men som helt central i intervjuernas perspektiv på kvalitet $i$ skådespelarens arbete framstår en term lånad från en annan konstart: musikalitet.

I varje intervju ställdes därför också följdfrågan: Kan du tänka dig en teaterform som aktivt och medvetet strävar efter att inte vara musikalisk? Åtskilliga svar på detta är kategoriska. "Nej. Det kan jag inte förstå. Det är otänkbart", svarar Ann Petrén. "Det låter skrämmande", säger Gösta Ekman. Och Rolf Lassgård intygar, med en formulering som tycks återknyta till uppfattningen att innebörden av teatermusikalitet ligger i att det finns 'liv' på scenen: "Det skulle dö. Det skulle bli dött. Jag lovar. En annan sak är ju hur medveten man är om det" (Bjerstedt, 2017, s. 152).

Hur teatermänniskor närmare uppfattar musikalitetens innebörder kommer till uttryck i många skiftande formuleringar $\mathrm{i}$ intervjuerna. Termen kan användas på flera nivåer: om text, om regi, om en föreställning, om en viss scen, eller om en enskild skådespelares insats. För Sissela Kyle kan 'musikalitet' fungera som en metafor på en lång rad olika sätt i teatersammanhang, beroende på hur man ser på musik som en parallell till teater. En aspekt är mera övergripande; den handlar om medvetenhet om 'musikaliska' kvaliteter som ton, tempo, rytm och pausering. En annan har att göra med receptiva kvaliteter: lybördhet, gehör och lyssnande. En tredje aspekt inriktar sig på det fysiska utförandet; den handlar om tempo och tajming i det aktiva gestaltandet (Bjerstedt, 2017, s. 84 f).

Det är lätt att uppfatta de två sistnämnda av de centrala perspektiv som Kyle här nämner som ett slags begreppspar som speglar dynamiken mellan två kompletterande förhållningssätt i musik och teater: lyssnande-gestaltande, 
lyhördhet-tajming, receptivitet-aktivitet. Många av de synpunkter på teatermusikalitet som kommer fram i intervjuerna låter sig också grupperas $\mathrm{i}$ ett sådant mönster. I en lång rad uttalanden nämner intervjupersonerna dels skådespelarens förmåga till lyssnande, att ta emot, dels mer aktiva förmågor, som kan sammanfattats under rubriken rytm.

En lyssnande musikalitet framstår i intervjuerna som central inte bara $i$ skådespelarens förhållande till den sceniska omgivningen, utan också i hennes förhållande till pjästexten. En pjästext tycks av intervjupersonerna kunna uppfattas som musikalisk, om dess författare har lyckats lyssna av samtiden; en uppsättning, om dess regissör lyckats lyssna av pjästexten. Kanske kan man i detta synsätt uppfatta ett slags kedja av lyssnande teatermusikalitet i flera led. Dramatikern lyssnar av sin samtid. Regissör och skådespelare lyssnar i sin tur av texten, och de måste lyssna av den tillräckligt bra för att resultatet ska kunna kommunicera med publiken. Vidare menar Henric Holmberg att musikalitet har en oerhört stor betydelse för skådespelares samspel, och Stina Ekblad beskriver det sceniska samspelet som ett musicerande (Bjerstedt, 2017, s. 101).

Skådespelarmusikalitet tycks också handla om att balansera, att tolka texten. Ingen människa förmår lyssna på allting samtidigt. Det är helt enkelt nödvändigt att en teaterföreställning "orkestreras", för att man ska uppnå balans och fokus på rätt sak. Stina Ekblad pekar på hur musikalitet i teatern handlar om frågan "vad är det just nu som är viktigast?" För Staffan Göthe är teaterns regi en motsvarighet till musikens orkestrering. Iwar Wiklander beskriver denna kvalitet i termer av fokus, och Göran Stangertz gör en sammankoppling mellan de båda begreppen: orkestreringens syfte är att åstadkomma balans och fokus på rätt sak (Bjerstedt, 2017, s. 145 f). I musik är det tonsättaren som orkestrerar. Men i teater kan motsvarande uppgift också ligga på den enskilda skådespelaren, menar Göran Stangertz (Bjerstedt, 2017, s. 96). En 'musikalisk' regi behöver enligt intervjupersonerna emellertid inte nödvändigtvis uppfattas som en regi med en bestämd estetisk måttstock när det gäller kvaliteter som exempelvis balans, fokus, tempo och rytm, även om något slags sådan måttstock kanske ofta dominerar - snarare som en regi med uppdriven medvetenhet beträffande sådana kvaliteter (Bjerstedt, 2017, s. 148).

Ett skäl till att teatern har lånat många uttryck från musiken kan vara att man upplever dem som mer exakta än teaterns eller vardagsspråkets termer. Lena Endre påpekar att delar av teaterspråket med nödvändighet blir metaforiskt och ungefärligt, och att musiktermerna här kan erbjuda en kontrast: "De musikaliska termerna är bra när man talar om teater [...] eftersom vi inte har något exakt språk för det vi gör" (Bjerstedt, 2017, s. 114). Ann Petrén påpekar att det musikaliska språkbruket kan påverka valet av vägar som skådespelaren använder för att närma sig känslan. 
Det är ju ett redskap, de här musikaliska termerna. För att komma åt en känsla, för att inte prata om känslan. Man vet att om man börjar springa så kan man framkalla känslan av att vara jagad, eller rädsla. (Bjerstedt, 2017, s. 115)

Stina Ekblad menar att hennes teatersyn kan ha något med hennes musikaliska preferenser att göra:

Jag är uppvuxen i en viss kulturkrets. Jag dras åt västerländsk klassisk konstmusik. Man kan bryta mot reglerna, man kan improvisera kring dem $[\ldots]$ men det finns ändå en grundläggande [...] balans och harmoni. (Bjerstedt, 2017, s. 115 f)

Rolf Lassgård pekar på att flera slags musik kan vara värdefulla för skådespelaren, och han anknyter till musiktermer som legato (bundet framförande) och staccato (framförande med korta uppehåll):

Jag minns ju hur man som ung kämpade stenhårt för att hitta det här med legato och staccato [...] klassisk musik, de här långa linjerna, så att man får in det, men även bluesen, som har det där att den kan töja och förlänga... (Bjerstedt, 2017, s. 118)

Om Stina Ekblad är den klassiska musikens förespråkare när det gäller teatermusikalitet, så är Ann Petrén en jazzambassadör:

I en uppsättning med många människor tänker man ju att man är solostämman ibland, kompet ibland. När man beskriver en sådan improvisation tänker man: det är ju så där pjäser är skrivna. Jazzen är en sorts vision. [...] Strikta regler, och så inom dem får man göra nästan vad man vill. [...] Alla drömmer ju om att teater ska vara som jazz. (Bjerstedt, 2017, s. 119)

Staffan Göthe tycker att allätarens inställning är den mest fruktbara:

Jag tycker att man kanske i så fall skulle göra väldigt oheliga kombinationer. Man använder den billigaste schlagermusik, och plötsligt är det Prokofjev eller Schubert. En stor allmänning. (Bjerstedt, 2017, s. 120)

Mia Höglund Melin för fram tanken att strävan efter nya slag av musikalitet kan ingå som en viktig del $\mathrm{i}$ arbetet med att förnya teatern:

Jag tänker att det måste finnas något annat än jazz... Den teater som händer nu, det är mer bara trummor liksom. Det är en modig generation 
som kommer nu. De är intresserade av att spela på ett nytt sätt. (Bjerstedt, 2017, s. 154 f)

Estetiska preferenser beträffande musik tycks kort sagt kunna ha ett avgörande inflytande på hur skådespelare ser på sitt arbete - både i ett övergripande estetiskt perspektiv och i ett konkret hantverksperspektiv.

\section{'Musikalitet' i teaterpedagogiken}

I undersökningen med teaterpedagoger (Bjerstedt, 2010) svarar intervjupersonerna enhälligt på frågan om det finns skådespelare som inte vill agera musikaliskt: "Det låter orimligt" (s. 101). I en ganska generell mening tycks ordet musikalitet av dem uppfattas som synonymt med 'liv'. Rörelse-läraren Barbara Wilczek Ekholm säger:

Pausen hör till aktiviteterna. När det kopplas fritt och syret tar slut i gestaltningen, föreställningen, då menar jag att det saknas musikalitet. (Bjerstedt, 2010, s. 78)

Röstläraren Harald Emgård poängterar att medvetenhet om pausernas betydelse är ett viktigt utbildningsmål.

Att uppmärksamma elever på tystnad och paus - det är faktiskt en jättestor avdelning i utbildningen. (Bjerstedt, 2010, s. 78 f)

Scenframställningsläraren Marek Kostrzewski beskriver hur begreppet puls kan bidra till att ge studenterna en tydlig och direkt nyckel till rollfigurerna och den sceniska situationen. Ett annat musikaliskt begrepp som kan vara fruktbart i skådespelarstudenternas arbete, särskilt i de inledande faserna av repetitionsarbetet, är improvisation. Scenframställningsläraren Birgitta Vallgårda uttrycker det som ett sätt att okka pjästextens angelägenhetsgrad. Detta uppnås genom att improvisationerna skapar ett alltmer konkret och specificerat uttrycksbehov - ett behov som sedan tillfredsställs av den skrivna pjästexten.

Att arbeta med text, att exempelvis hitta rytmen $i$ en prosatext, ser intervjupersonerna som ett kroppsarbete. Röstläraren Margareta Unné Göransson säger: "Man måste upp på golvet. Med kropp och andning. Och hitta det organiskt" (Bjerstedt, 2010, s. 80). Ett aktivt förhällande till rytmen förefaller alltså vara ett väsentligt inslag i teaterområdets musikalitetsbegrepp. Scenframställningsläraren Marek Kostrzewski använder ett åskådligt exempel för att visa hur skådespelare genom att forma texten musikaliskt kommer att skapa betydelser. Att lära sig forma texten musikaliskt innebär att skådespelaren lär sig att forma innehållet, att skapa en betydelse. Betydelsen skapar sedan i sitt sammanhang berättelsen, som publiken uppfattar (Bjerstedt, 2010, s. 86). 
Att repetera liknas i Kostrzewskis beskrivning vid att skapa en notbild - ett partitur. Detta ligger sedan till grund för föreställningarna, som alla kommer att utgöra tolkningar av detta partitur. Förmågan till ett sådant medvetet partiturbyggande framstår för Kostrzewski som ett helt centralt utbildningsmål.

I musiken finns begreppet periodkänsla som beteckning för en utövande musikers förmåga att $\mathrm{i}$ rätt ögonblick vara på rätt plats $\mathrm{i}$ den musikaliska perioden. Som en motsvarighet i teatern skulle man kunna uppfatta den förmåga som enligt rörelseläraren Barbara Wilczek Ekholm är av central betydelse för skådespelaren: att $i$ rätt ögonblick vara på rätt plats $i$ det sceniska rummet (Bjerstedt, 2010, s. 90). I flera intervjuer nämns oförmåga att placera sig i rummet som ett tydligt symptom på bristande scenisk musikalitet.

Rörelseläraren Barbara Wilczek Ekholm pekar ut närvaro som en nödvändig förutsättning för att agera musikaliskt.

Man måste lyssna, man måste se, man måste bedöma, hela tiden, vad det är som sker just nu på scenen. [...] Utan avspänning så kan du inte öppna alla sinnen. [...] Annars så är du inte i rätt tid på rätt plats. Är du spänd så bommar du. (Bjerstedt, 2010, s. 92 f)

Intervjupersonerna framhåller att en 'stum', 'avstängd' kropp kan hämma skådespelarens närvaro, som de beskriver $\mathrm{i}$ termer av öppenhet och mottaglighet, och de ser orsaken till sådana hämningar i för hög mental och fysisk anspänning. Att träna avspänning är enligt intervjupersonerna en del av vägen mot att agera musikaliskt - men de ser den inte som tillräcklig.

\section{TRE SLAGS FÖRMÅGOR}

I resultaten från intervjuer med teaterkonstnärer och teaterpedagoger framtonar en komplex bild av musikalitetens innebörd på teaterområdet, där rytm ingår som en aspekt bland många. Synen på skådespelarens musikalitet kan i flera avseenden uppfattas som både rikt sammansatt och annorlunda än den på musikområdet vanliga musikalitetsuppfattningen. I detta avsnitt analyseras detta synsätt som en kombination av tre slags förmågor.

Ett samlat intryck av intervjuerna är att en skådespelares förmåga att "agera musikaliskt" kan uppfattas som sammansatt av en rad förmågor som kompletterar varandra. Tre nyckelord kan betraktas som särskilt viktiga: NÄRVARO, STRUKTUR och FLÖDE. (En viss godtycklighet i ordvalet är ofrånkomlig. Alternativa benämningar skulle kanske kunna vara sinnlighetplan-samspel, eller nu-känsla-orkestrering-kommunikation. Detta sagt mest som en påminnelse om ordens makt - och deras otillräcklighet.) Var och en av dessa termer ska här uppfattas som beteckning för en samling kvaliteter och förmågor som är centrala för skådespelarens musikalitet. Alla dessa förmågor 
hänger nära samman: NÄRVARO-förmåga, STRUKTUR-förmåga och förmåga till FLÖDE är integrerade och avhängiga av varandra. De griper in i, samverkar med och förutsätter varandra $-i$ rummet, $i$ tiden och i samspelet.

\section{Närvaro}

Det är viktigt att kunna vara och agera bär och nu med alla sinnen. Om skådespeleriet ska upplevas som trovärdigt av publiken, är skådespelarens förmåga till närvaro avgörande. Det är en kvalitet som kan uttryckas på olika sätt. Rörelseläraren Margareta Unné Göransson säger: "det största hotet för skådespelarens del i icke-musikalitet, det är icke-närvaro. För man måste lyssna, man måste se, man måste bedöma, hela tiden, vad det är som sker just nu på scenen" (Bjerstedt, 2010, s. 92). Marie Richardson formulerar närvaro i termer av fokus, men också lust, nyfikenhet och respekt 1 förhållande till medspelaren: att ha "alla sinnen öppna". Staffan Göthe och Mia Höglund Melin talar om modet att utsätta sig för nuet. Det måste "leva", understryker flera skådespelare. Gösta Ekman talar om längtan efter en "maximal nu-upplevelse". Stina Ekblad liknar musikaliteten vid en "situationskänsla". "När alla glömmer sig men ändå håller sina överenskommelser, då svänger det", säger Marie Richardson. Staffan Göthe beskriver det som att man "tar ner garden", "att man vågar ha en viss improvisatorisk hållning". För Lena Endre är det också fråga om en "rumslig begåvning", en teknisk behärskning som gör det möjligt att vara på rätt plats vid rätt tillfälle (Bjerstedt, 2017, s. 163 f).

Att agera musikaliskt med NÄRVARO kan bland annat innebära att ha modet att kasta sig ut i det okända, att ha sitt fokus hos medspelarna, att vara på rätt plats i rätt ögonblick och att ha en maximal öppenhet för det nya, för nuet.

\section{Struktur}

Det är också viktigt för skådespelaren att kunna uppfatta, analysera och bygga strukturer. Av skådespelaren krävs dels en medvetenhet om "musikaliska mönster" i en pjästext, dels en förmåga att förvalta dessa mönster. Scenframställningsläraren Marek Kostrzewski menar att "musikalitet är ett verktyg som hjälper oss att organisera saker och ting ... att organisera enstaka element i en form. [...] För mig är musikalitet kunskapen om att det som händer nu, det är resultatet av det som hände då, och de två ihop tvingar mig, ger mig inte frihet... Det är som att åka bobsleigh” (Bjerstedt, 2010, s. 83, 87). Göran Stangertz betonar hur viktigt det är att 'orkestrera' en teaterföreställning: att balansera och tolka texten, så att publiken uppfattar det som ska uppfattas. Ansvaret för detta kan också ligga på den enskilda skådespelaren. Här är rytmisering av stor betydelse, liksom hur fokus placeras och flyttas - alltså samspelet mellan skådespelarna. 'Musikalitet' på teaterområdet innebär för flera intervjupersoner (exempelvis Stina Ekblad och Sissela Kyle) en medvetenhet om kvaliteter som ton, tempo, rytm och 
pausering. För många (exempelvis Ann Petrén och Mia Höglund Melin) verkar strävan efter kontraster, variationer i rytm och dynamik vara central. Tobias Theorell talar om vikten av att göra rytmväxlingar, och att fylla även pauser med energi och laddning (Bjerstedt, 2017, s. 164 f).

Kategorin STRUKTUR är mångfasetterad: dit hör rumsliga aspekter som rörelse, placering och tajming, men också strävan efter rollernas individualisering bland annat genom språket, den tonträff som så många talar om. Att agera musikaliskt med STRUKTUR kan bland annat innebära att uppfatta variationerna och motsättningarna $i$ en text, att se helheten, att identifiera och förhålla sig till textens musikaliska kvaliteter, att skapa betydelser och bygga en helhet genom att forma texten musikaliskt i tiden och i rummet.

\section{Flöde}

Det är också viktigt för en skådespelare att kunna vara och agera fri, avspänd, aktiv och öppen. Flera intygar att skådespelarinsatsen måste ha det de kallar liv. Om publiken upplever det, ger det en känsla av säkerhet och trygghet. Skådespeleriet ska också ha liv i bemärkelsen att det inte är en mekanisk upprepning.

Flera framhåller också kommunikation som ett centralt mål för skådespeleriet: "om det inte kommunicerar, då är inte tekniken något värd", säger Henric Holmberg. Sissela Kyle påpekar hur samspelet med publiken handlar om en dubbelriktad lyhördhet och ett spel med förväntningar (Bjerstedt, 2017, s. 165). Rörelseläraren Barbara Wilczek Ekholm säger: "När det svänger på scenen, då svänger det mellan skådespelarna - och salongen" (Bjerstedt, 2010, s. 79).

Här kan Sture Brändströms (2006) begrepp relationell musikalitet - som formulerades med fokus på musikens kommunikativa aspekter - vara av vikt också för att förstå musikalitetens funktion i skådespelarkonsten. Mot kommunikation som en aktiv aspekt av skådespeleri svarar en receptiv aspekt: lyhördhet, gehör och lyssnande. Det är också en innebörd av musikalitetsbegreppet som återkommer i flera uttalanden. "Det vi mest menar med musikalitet, det är lyhördheten i samspelet", säger Iwar Wiklander (Bjerstedt, 2017, s. 165). Det som här betecknas med rubriken FLÖDE består till väsentlig del av dynamiken mellan lyssnande och gestaltande, mellan lyhördhet och rytm/tajming, mellan receptivitet och aktivitet. Flera skådespelare nämner hur man når flow genom öppenhet, genom att relatera till omständigheterna.

Tobias Theorell säger: "Min medspelare är väldigt närvarande, och jag får kontakt. Publiken lyssnar och är samspelt. Och också känslan av flow.” Gösta Ekman talar om längtan att nå det okända, en maximal nu-upplevelse. Skådespelarens musikalitet kan framstå som något musikantiskt snarare än musikaliskt. Marie Richardson säger: "Att bolla ... det är ju ett slags 
musikalitet, men det går inte att säga att den är som vanlig musikalitet" (Bjerstedt, 2017, s. 166).

Att agera musikaliskt med FLÖDE kan bland annat innebära att leva, att agera fritt och avspänt, att samspela, att arbeta rytmiskt i röst och kropp, att driva, att växla rytm och att vara aktiv.

\section{KONKLUSION}

Urvalet av intervjupersoner, deras åldersfördelning och teatererfarenheter kan självfallet ha påverkat undersökningsresultatet. Ett exempel belyser hur olika slags teatersyn eller 'estetik' kan hänga samman med intervjusvarens olika karaktär. I intervjuerna framtonar tre olika bilder av teater som musik: teater som kammarmusik, med fokus på interpretation av dramatikerns intention, teater som jazz, med fokus på att flexibelt relatera till helheten - eller teater som "mer bara trummor liksom" (Bjerstedt, 2017, s. 157). Urvalets inriktning på personer med lång och bred teatererfarenhet kan ha medfört att studien $\mathrm{i}$ mindre utsträckning beaktat synpunkter från yngre teaterarbetare med andra estetiska preferenser. Denna insikt innebär rimligen inte att studien förlorar sitt värde, men den ger anledning till fortsatta undersökningar.

Termen 'musikalisk' har fått en position som sällan ifrågasatt paraplyterm för en mängd eftersträvansvärda förmågor. Det förefaller möjligt att uppfatta termen på teaterområdet som en metafor, fiktion eller konstruktion. Här kan perspektiv från Vaihingers (1911) fiktionalism vara relevanta men i ännu högre grad senare teorier som conceptual metaphor (Lakoff \& Johnson, 1980) och conceptual blending (Fauconnier \& Turner, 2002). Fruktbara i sammanhanget är troligen också Max Blacks (1962) och Paul Ricoeurs (1975/2003) påpekanden om metaforers interaktiva funktion: metaforiskt tal erbjuder en ny verklighetsbeskrivning. Metaforen låter oss se verkligheten på nytt; den är ett redskap för upptäckter.

Diskursanalytikern Jonathan Potter (1996) har pekat på hur beskrivningar kan analyseras både som handlingar och som konstruktioner av fakta. Enskilda intervjuuttalanden pekar på att termen 'musikalitet' också används preskriptivt på teaterns område. David Roesner (2014) ser musikalitetsbegreppet på teaterns område som ett dispositif $\mathrm{i}$ Foucaults mening: som mekanismer och strukturer för maktutövande. Med utgångspunkt i studiens resultat kan musikalitetsbegreppet på teaterområdet tolkas som en social konstruktion som fungerar normativt (Bjerstedt, 2017, s. 158-163).

Skådespelarens musikalitet framstår som en kroppslig och en intellektuell men också en holistisk förmåga. NÄRVARO, STRUKTUR och FLÖDE griper in i, samverkar med och förutsätter varandra. Tonvikten kan sannolikt placeras ganska olika i enskilda fall, men med utgångspunkt $i$ intervjuresultaten verkar det rimligt att se alla de tre ingående del-förmågorna som nödvändiga (men var för sig inte tillräckliga) förutsättningar för det som har kallats 
skådespelarens musikalitet. Förmågan att agera musikaliskt innebär att vara och agera här och nu med alla sinnen, att uppfatta, analysera och bygga strukturer samt att vara och agera fri, avspänd, aktiv och öppen.

Konstnärers och pedagogers användning av musikalitetsbegreppet på teaterområdet har visats vara ett betydelsefullt redskap för konstnärlig kunskapsbildning och konstnärligt lärande. Begreppsanvändningen framstår som intressant både genom sin karaktär av intermedialt begreppslån och genom hur den exemplifierar den språkliga metaforens potential för konceptualiserings- och lärandeprocesser. I båda avseendena bör det studerade fenomenet kunna stimulera till framtida undersökningar av lärande på det konstnärliga området.

Den bild av musikalitet som tonar fram på teaterns område är rik. I förhållande till tidigare musikalitetsforskning kan den kanske framstå som originell med sitt framhävande av begreppen NÄRVARO, STRUKTUR och FLÖDE. Möjligheten att återföra denna bild av musikalitet till musikområdet och pröva den där framstår också som en lockande uppgift för fortsatt forskning.

\section{REFERENSER}

Alvesson, Mats; \& Sköldberg, Kaj (2008). Tolkning och reflektion: Vetenskapsfilosofi och kvalitativ metod. (2:a uppl.) Lund: Studentlitteratur.

Ashperger, Cynthia (2008). The rhythm of space and the sound of time. Michael Chekhov's acting technique in the 21st century. Amsterdam: Rodopi.

Bergman, Gösta M. (1966). Den moderna teaterns genombrott 1890-1925. Stockholm: Bonnier.

Berry, Cicely (1987). The actor and his text. London: Virgin.

Bjerstedt, Sven (2010). Att agera musikaliskt: Musikalitet som norm och utbildningsmål $i$ västerländsk talteater. [Masteruppsats.] Lunds universitet: Musikhögskolan i Malmö.

Bjerstedt, Sven (2014). Storytelling in jazz improvisation: Implications of a rich intermedial metaphor. [Doktorsavhandling.] Lunds universitet: Musikhögskolan i Malmö.

Bjerstedt, Sven (2017). Skådespelarens musikalitet. Möklinta: Gidlund.

Black, Max (1962). Models and metaphors: Studies in language and philosophy. Ithaca: Cornell University Press.

Boleslavsky, Richard (1933/2003). Acting. The first six lessons. New York \& London: Routledge.

Brockett, Oscar G. (1995) History of the theatre. Seventh edition. Needham Heights, MA: Allyn \& Bacon. 
Brändström, Sture (1997). Vem är musikalisk? Intervjuer med musiklärare och musiklärarutbildare. Stockholm: KMH Förlaget (Pedagogiska publikationer från Kungliga Musikhögskolan).

Brändström, Sture (2006). Musikalitet och lärande. I Eva Alerby \& Jórunn Elídóttir (red:er), Lärandets konst - betraktelser av estetiska dimensioner i lärandet (s. 143-155). Lund: Studentlitteratur.

Carnegy, Patrick (2006). Wagner and the art of the theatre. New Haven, CT: Yale University Press.

Chekhov, Michael (1992). On the technique of acting.New York: Harper Collins.

Fauconnier, Gilles \& Turner, Mark (2002). The way we think: Conceptual blending and the mind's hidden complexities. New York: Basic Books.

Gladkov, Aleksandr (1996). Meyerhold speaks, Meyerhold rehearses. Amsterdam: Harwood Academic.

Helander, Paula (2007). Rytmik, för skådespelare: Vad kan en rytmikpedagog tillföra i en högre teaterutbildning? [Examensarbete.] Malmö: Lunds universitet, Musikhögskolan i Malmö.

Johansson, Stefan (2006). Talad teater - en tongivande parentes? Teatertidningen, (4), s. 26-27.

Johnson, Mark (1987). The body in the mind: The bodily basis of meaning, imagination, and reason. Chicago: University of Chicago Press.

Jouvet, Louis (1954). Le comédien désincarné. Paris: Flammarion.

Kvale, Steinar (1997). Den kvalitativa forskningsintervjun. Lund: Studentlitteratur.

Lakoff, George \& Johnson, Mark (1980). Metaphors we live by. Chicago \& London: University of Chicago Press.

Leach, Robert (2000). Meyerhold and biomechanics. I Alison Hodge (red.) Twentieth century actor training (s. 37-54). London \& New York: Routledge.

Lind, Torbjörn; \& Bornholm, Helena (2013). Vetenskapsrådets symposium nr 3 om konstnärlig forskning. I Torbjörn Lind (red.), Konstnärlig forskning då och nuArtistic research then and now 2004-2013. Årsbok KFoU (s. 190-196). Stockholm: Vetenskapsrådet.

Malloch, Stephen, \& Trevarthen, Colwyn (2008). Communicative musicality: Exploring the basis of human companionship. Oxford: Oxford University Press.

Pauli Jensen, Jørgen (1977). Musikens psykologi och sociologi. Stockholm: AWE/Gebers.

Petrie, Hugh G., \& Oshlag, Rebecca S. (1993). Metaphor and learning. In Andrew Ortony (Ed.), Metaphor and thought. Second edition (s. 579-609). Cambridge: Cambridge University Press.

Potter, Jonathan (1996). Representing reality: Discourse, rhetoric and social construction. London: Sage. 
Ricoeur, Paul (1975/2003). The rule of metaphor: The creation of meaning in language. (Övers. R. Czerny, K. McLaughlin \& J. Costello.) London \& New York: Routledge.

Rodenburg, Patsy (2002). Speaking Shakespeare. London: Methuen.

Roesner, David (2014). Musicality in theatre: Music as model, method and metaphor in theatre-making. Farnham, UK: Ashgate.

Rynell, Erik (2008). Action reconsidered. Cognitive aspects of the relation between script and scenic action. [Doktorsavhandling.] Helsingfors: Teaterhögskolan. (Acta Scenica 22.)

Schippers, Huib (2006). 'As if a little bird is sitting on your finger...': metaphor as a key instrument in training professional musicians. Internation journal of music education, 24(3), s. 209-217.

Sjögren, Henrik (2002). Lek och raseri. Ingmar Bergmans teater 1938-2002. Stockholm: Carlssons.

Staniewski, Włodzimierz \& Hodge, Alison (2003). Hidden territories. The theatre of Gardzienice. London: Routledge.

Stanislavski, Konstantin (2008). An actor's work. (Eng. Övers. Jean Benedetti.) London \& New York: Routledge.

Strindberg, August (1908/1999). Teater och Intima teatern. Stockholm: Norstedt.

Swanwick, Keith (1988). Music, mind, and education. London: Routledge.

Tjäder, Per-Arne (2008). Uppfostran - underhållning - uppror. En västerländsk teaterhistoria. Lund: Studentlitteratur.

Vaihinger, Hans (1911). Die Philosophie des Als Ob. System der theoretischen, praktischen und religiösen Fiktionen der Menschbeit auf Grund eines idealistischen Positivismus. Mit einem Anhang über Kant und Nietzsche. Berlin: Reuther \& Reichard.

Whyman, Rose (2008). The Stanislavsky system of acting. Legacy and influence in modern performance. Cambridge University Press. 